\title{
Haloplanus aerogenes sp. nov., an extremely halophilic archaeon from a marine solar saltern
}

Correspondence

Heng-Lin Cui

cuihenglin@sohu.com

\author{
Heng-Lin Cui, ${ }^{1}$ Xia Gao, ${ }^{1}$ Xin Yang ${ }^{1}$ and Xue-Wei $X^{2}$
}

\author{
${ }^{1}$ School of Food \& Biological Engineering, Jiangsu University, Zhenjiang 212013, PR China \\ ${ }^{2}$ Second Institute of Oceanography, State Oceanic Administration, Hangzhou 310012, PR China
}

\begin{abstract}
Halophilic archaeal strain TBN37 ${ }^{\top}$ was isolated from Taibei marine solar saltern near Lianyungang city of Jiangsu province, China. Cells were pleomorphic, flat and contained gas vesicles. Cells of strain TBN37 $7^{\top}$ stained Gram-negative and the colonies were pink-pigmented. The strain was able to grow at $25-50{ }^{\circ} \mathrm{C}$ (optimum, $37-40{ }^{\circ} \mathrm{C}$ ), with 1.4-5.1 M NaCl (optimum, $2.1 \mathrm{M} \mathrm{NaCl}$ ), with 0-1.0 M MgCl 2 (optimum, $0.01 \mathrm{M} \mathrm{MgCl}_{2}$ ) and at $\mathrm{pH}$ 6.0-9.0 (optimum, $\mathrm{pH} 7.5$ ). Cells lysed in distilled water and the minimal $\mathrm{NaCl}$ concentration to prevent cell lysis was $8 \%(\mathrm{w} / \mathrm{v})$. The major polar lipids of strain TBN3 $7^{\top}$ were phosphatidylglycerol, phosphatidylglycerol phosphate methyl ester, phosphatidylglycerol sulfate and one major glycolipid chromatographically identical to sulfated mannosyl glucosyl diether (S-DGD-1). On the basis of 16S rRNA gene sequence analysis, strain TBN37 ${ }^{\top}$ was closely related to Haloplanus natans and Haloplanus vescus, with the same similarity of $97.4 \%$. The DNA G $+\mathrm{C}$ content of strain TBN37 ${ }^{\top}$ is $64.1 \mathrm{~mol} \%$. DNA-DNA hybridization values between strain TBN37 ${ }^{\top}$ and Haloplanus natans JCM $14081^{\top}$ and between strain $\mathrm{TBN}^{\mathrm{T}} 7^{\top}$ and Haloplanus vescus $\mathrm{RO}$ - ${ }^{\top}{ }^{\top}$ were $37.6 \%$ and $42.1 \%$, respectively. It was concluded that strain TBN3 $37^{\top}$ represents a novel species of the genus Haloplanus, for which the name Haloplanus aerogenes sp. nov. is proposed. The type strain is TBN3 $7^{\top}$ (=CGMCC $1.10124^{\top}=$ JCM $16430^{\top}$ ).
\end{abstract}

Halophilic archaea, members of the family Halobacteriaceae, have been isolated from various hypersaline environments and are currently classified into more than 27 genera (Oren et al., 2009). The genus Haloplanus was first proposed by Bardavid et al. to accommodate three flat-shaped strains isolated from an experimental mesocosm filled with a mixture of water from the Dead Sea and the Red Sea, Israel (Bardavid et al., 2007). More recently, Haloplanus vescus (Cui et al., 2010), a novel species isolated from Rudong marine solar saltern located in Jiangsu Province of China, was added to the genus Haloplanus. The most interesting characteristic of members of this genus is that their cells are pleomorphic and flat, and in static liquid medium always float to the surface, which reveals that they may contain gas vesicles. In 2008, during our surveys on halophilic archaeal diversity of Taibei marine solar saltern, another marine solar saltern near Lianyungang city of Jiangsu province, an extremely halophilic archaeal strain related to the genus

Abbreviations: PG, phosphatidylglycerol; PGP-Me, phosphatidylglycerol phosphate methyl ester; PGS, phosphatidylglycerol sulfate; S-DGD-1, sulfated mannosyl glucosyl diether.

The GenBank/EMBL/DDBJ accession number for the 16S rRNA gene sequence of strain TBN37 ${ }^{\top}$ is GQ282625.

Three supplementary figures are available with the online version of this paper.
Haloplanus was obtained. In this study, we characterize strain $\mathrm{TBN} 37^{\mathrm{T}}$ as a novel species of the genus Haloplanus.

Strain $\mathrm{TBN}^{2} 7^{\mathrm{T}}$ was isolated from sediment of Taibei marine solar saltern $\left(34^{\circ} 43^{\prime} 38^{\prime \prime} \mathrm{N} 119^{\circ} 17^{\prime} 48^{\prime \prime} \mathrm{E}\right)$, which is an artificial marine solar saltern near Lianyungang city of Jiangsu province, China. The neutral oligotrophic haloarchaeal medium (NOM) used for the isolation procedure contained the following ingredients $\left(\mathrm{g} \mathrm{l}^{-1}\right)$ : yeast extract, 0.05 ; fish peptone, 0.25 ; sodium pyruvate, 1.0 ; $\mathrm{KCl}, \quad 5.4 ; \quad \mathrm{K}_{2} \mathrm{HPO}_{4}, \quad 0.3 ; \quad \mathrm{CaCl}_{2}, 0.25 ; \quad \mathrm{NH}_{4} \mathrm{Cl}, \quad 0.25$; $\mathrm{MgSO}_{4} \cdot 7 \mathrm{H}_{2} \mathrm{O}, 26.8 ; \mathrm{MgCl}_{2} .6 \mathrm{H}_{2} \mathrm{O}, 23.0 ; \mathrm{NaCl}, 184.0$ ( $\mathrm{pH}$ adjusted to 7.0-7.2 with $1 \mathrm{M} \mathrm{NaOH}$ solution) (Cui et al., 2010). The medium was solidified with $2.0 \%$ agar. The strains were routinely grown aerobically at $37{ }^{\circ} \mathrm{C}$ in NOM-3 medium (NOM series medium) with the following modifications $\left(\mathrm{g} \mathrm{l}^{-1}\right)$ : yeast extract, 1.0 ; fish peptone, 0.25 ; sodium formate, 0.25 ; sodium acetate, 0.25 ; sodium lactate, 0.25 ; sodium pyruvate, 0.25 .

Phenotypic tests were performed according to the proposed minimal standards for description of new taxa in the order Halobacteriales (Oren et al., 1997). The type strains Haloplanus natans JCM $14081^{\mathrm{T}}$, Haloplanus vescus RO5-8 ${ }^{\mathrm{T}}$ and Haloferax elongans JCM $14791^{\mathrm{T}}$ together with strain Halobacterium salinarum CGMCC 1.2367 (=ATCC 33170) were selected as reference strains for positive and negative testing. Cell morphology and motility in exponentially 
growing liquid cultures were examined using a Nikon microscope equipped with phase-contrast optics (model E400). The minimal salt concentration to prevent cell lysis was tested by suspending washed cells in serial sterile saline solutions containing $\mathrm{NaCl}$ ranging from 0 to $15 \%(\mathrm{w} / \mathrm{v})$, and the stability of the cells was detected by light microscopic examination.

The Gram stain was performed by following the method outlined by Dussault (1955). Most miscellaneous biochemical tests and nutritional tests were performed as described and proposed by Oren et al. (1997). Briefly, growth and gas formation with nitrate as electron acceptor were tested in $9 \mathrm{ml}$ stoppered tubes, completely filled with liquid NOM medium to which $\mathrm{NaNO}_{3}\left(5 \mathrm{~g} \mathrm{l}^{-1}\right)$ had been added, and containing an inverted Durham tube. The formation of gas from nitrate was detected by the presence of gas bubbles in Durham tubes and the formation of nitrite was monitored colorimetrically. Anaerobic growth in the presence of $\mathrm{L}$-arginine and DMSO $\left(5 \mathrm{~g} \mathrm{l}^{-1}\right)$ was tested in completely filled $9 \mathrm{ml}$ stoppered tubes. Starch hydrolysis was determined on NOM agar plates supplemented with $2 \mathrm{~g} \mathrm{l}^{-1}$ soluble starch and detected by flooding the plates with Lugol's iodine solution. Gelatin hydrolysis was performed by growing colonies on NOM agar plates amended with $1 \%(w / v)$ gelatin and flooding the plates with Frazier's reagent (McDade \& Weaver, 1959) after growth was established. Esterase activity was detected as outlined by Gutiérrez \& González (1972). Tests for catalase and oxidase activities were performed as described by Gonzalez et al. (1978). Production of $\mathrm{H}_{2} \mathrm{~S}$ was tested by growing the isolates and reference strains in a tube with the NOM liquid medium supplemented with $0.5 \%(\mathrm{w} / \mathrm{v})$ sodium thiosulfate; a filter-paper strip impregnated with lead acetate was used for $\mathrm{H}_{2} \mathrm{~S}$ detection (Cui et al., 2007). To test for growth on single carbon sources, fish peptone and sodium pyruvate were omitted from the NOM medium and the compound to be tested was added at a concentration of $5 \mathrm{~g} \mathrm{l}^{-1}$. Antibiotic susceptibilities were determined by the Gutiérrez (Gutiérrez et al., 2008) method on NOM agar plates with antibiotic discs containing the following concentrations ( $\mu \mathrm{g}$ per disc, unless otherwise indicated): ampicillin (10), anisomycin (20), aphidicolin (20), bacitracin (0.04 IU per disc), chloramphenicol (30), ciprofloxacin (5), erythromycin (15), gentamicin (10), kanamycin (30), nalidixic acid (30), neomycin (30), norfloxacin (10), novobiocin (30), penicillin G (10 IU per disc), rifampicin (5), streptomycin (10), tetracycline (30) and vancomycin (30).

Polar lipids were extracted using a chloroform/methanol system and analysed using one- and two-dimensional TLC, as described by Kates (1986). Merck silica gel $60 \mathrm{~F}_{254}$ aluminium-backed thin-layer plates were used in TLC analysis. In two-dimensional TLC, the first solvent is chloroform/methanol/water $(65: 25: 4$, by vol. $)$ and the second solvent is chloroform/methanol/acetic acid/water $(80: 12: 15: 4$, by vol.), which is also used in onedimensional TLC. All TLC plates were sprayed with sulfuric acid/ethanol $(1: 2, \mathrm{v} / \mathrm{v})$ followed by heating at $150{ }^{\circ} \mathrm{C}$ for 3 min to detect phospholipids and glycolipids.

Genomic DNA from halophilic archaeal strains was prepared as described by $\mathrm{Ng}$ et al. (1995). The $16 \mathrm{~S}$ rRNA gene was amplified via PCR by using primers $0018 \mathrm{~F}$ and $1518 \mathrm{R}$ (Cui et al., 2009). PCR was performed in a thermal cycler (MJ Research PTC-150) for 30 cycles (5 min denaturing step at $95{ }^{\circ} \mathrm{C}$ in the first cycle; $1 \mathrm{~min}$ denaturing at $95{ }^{\circ} \mathrm{C}, 1 \mathrm{~min}$ annealing at $60{ }^{\circ} \mathrm{C}$ and $1.5 \mathrm{~min}$ elongation at $72{ }^{\circ} \mathrm{C}$; final extension step at $72{ }^{\circ} \mathrm{C}$ for $\left.10 \mathrm{~min}\right)$. The PCR products were examined on a $1.0 \%(\mathrm{w} / \mathrm{v})$ agarose gel and then cloned into the pEASY-T vector (TransGen Biotech) and transformed into cells of Escherichia coli Mach1. Ten transformants were randomly picked and sequenced at the Sino-GenoMax Company Limited (Beijing, China), to determine whether the two strains possessed multiple distinct 16S rRNA gene sequences. Multiple sequence alignments were performed using the CLUSTAL W program integrated in MEGA 4 software (Tamura et al., 2007). Phylogenetic trees were reconstructed using the neighbour-joining (Saitou \& Nei, 1987) and maximum-parsimony (Fitch, 1971) algorithms in MEGA 4 software including $16 \mathrm{~S}$ rRNA gene sequences representing genera of the family Halobacteriaceae with validly published names; phylogenetic trees representing just the most relevant branches are given. The percentages of replicate trees in which the associated taxa clustered together in the bootstrap test (1000 replicates) are shown next to the branches. 16S rRNA gene sequence similarity was calculated by comparison with sequences of related halophilic archaea from the online EzTaxon server (Chun et al., 2007). The DNA G + C content was determined by the HPLC method (Mesbah et al., 1989). DNA-DNA hybridization analyses were performed according to the thermal denaturation and renaturation method of De Ley et al. (1970) as modified by Huß et al. (1983).

Cells of strain $\mathrm{TBN} 37^{\mathrm{T}}$ were motile, pleomorphic and flat, and contained gas vesicles (see Supplementary Fig. S1 available in IJSEM Online). The cells stained Gram-negative and colonies were pink-pigmented. Strain $\mathrm{TBN} 37^{\mathrm{T}}$ was able to grow at $25-50{ }^{\circ} \mathrm{C}$ (optimum, 37-40 ${ }^{\circ} \mathrm{C}$ ), with $1.4-5.1 \mathrm{M}$ $\mathrm{NaCl}$ (optimum, $2.1 \mathrm{M} \mathrm{NaCl}$ ), with $0-1.0 \mathrm{M} \mathrm{MgCl}_{2}$ (optimum, $0.01 \mathrm{M} \mathrm{MgCl}_{2}$ ) and at $\mathrm{pH}$ 6.0-9.0 (optimum $\mathrm{pH}$ 7.5). Cells lysed in distilled water and the minimal $\mathrm{NaCl}$ concentration to prevent cell lysis was $8 \%(\mathrm{w} / \mathrm{v})$. Strain $\mathrm{TBN} 37^{\mathrm{T}}$ produced indole from tryptophan, but did not hydrolyse gelatin, Tween 80 , starch or casein. $\mathrm{H}_{2} \mathrm{~S}$ was not produced from sodium thiosulfate. The remarkable phenotypic characteristic that distinguished strain $\mathrm{TBN} 37^{\mathrm{T}}$ from Haloplanus natans JCM $14081^{\mathrm{T}}$ and Haloplanus vescus RO5$8^{\mathrm{T}}$ was that strain $\mathrm{TBN} 37^{\mathrm{T}}$ could grow under anaerobic conditions with nitrate and produce gas from nitrate, while related members of the same genus could not. More detailed results of phenotypic features of strain $\mathrm{TBN} 37^{\mathrm{T}}$ are given in the species description.

The polar lipids of strain $\mathrm{TBN} 37^{\mathrm{T}}$ were phosphatidylglycerol (PG), phosphatidylglycerol phosphate methyl ester (PGP-Me), phosphatidylglycerol sulfate (PGS), and one 


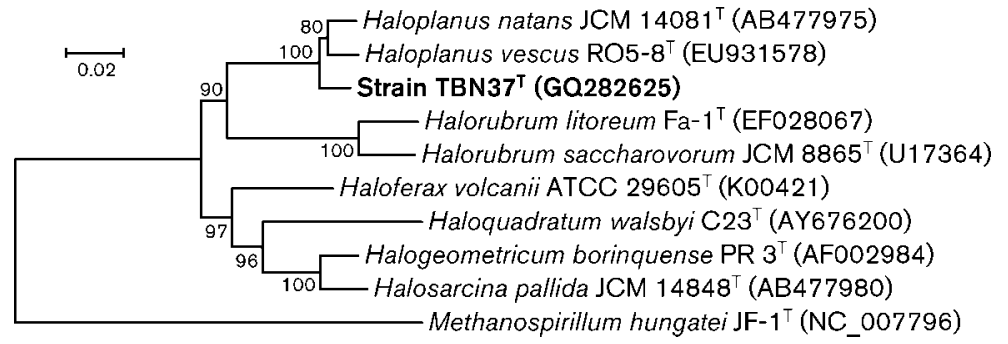

Fig. 1. Phylogenetic tree based on $16 \mathrm{~S}$ rRNA gene sequences showing the relationships

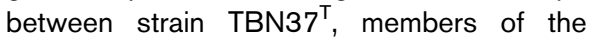
genus Haloplanus, and other related genera of the family Halobacteriaceae. Bootstrap values $(>70 \%)$ are given at nodes. Bar, 0.02 substitutions per site. major glycolipid chromatographically identical to sulfated mannosyl glucosyl diether (S-DGD-1), in a pattern chromatographically identical to the polar lipid profile of Haloplanus natans JCM $14081^{\mathrm{T}}$ (see Supplementary Fig. S2). The polar lipid composition supports classification of strain $\mathrm{TBN} 37^{\mathrm{T}}$ in the genus Haloplanus.

Ten complete 16S rRNA gene sequences of strain TBN37 ${ }^{\mathrm{T}}$ were obtained. Sequence comparisons indicated that strain $\mathrm{TBN} 37^{\mathrm{T}}$ has one kind of $16 \mathrm{~S}$ rRNA gene sequence. It was closely related to both Haloplanus natans and Haloplanus vescus, with the same similarity of $97.4 \%$. Phylogenetic analysis using the neighbour-joining algorithm revealed that strain $\mathrm{TBN}^{2} 7^{\mathrm{T}}$ clustered tightly with Haloplanus natans and Haloplanus vescus, forming a branch in the cluster with a bootstrap value of $100 \%$ (Fig. 1). The phylogenetic position was also confirmed in a tree generated using the maximum-parsimony algorithm (see Supplementary Fig. S3). The 16S rRNA gene-based phylogenetic analysis results supported the placement of strain TBN $37^{\mathrm{T}}$ in the genus Haloplanus.

The DNA G $+\mathrm{C}$ content of strain $\mathrm{TBN}^{2} 7^{\mathrm{T}}$ is $64.1 \mathrm{~mol} \%$, lower than those of strains representing Haloplanus natans (66.1-66.4 mol\%) (Bardavid et al., 2007) but higher than that of Haloplanus vescus RO5-8 ${ }^{\mathrm{T}}$ (62.1 mol\%). The DNADNA hybridization values between strain $\mathrm{TBN} 37^{\mathrm{T}}$ and Haloplanus natans JCM $14081^{\mathrm{T}}$ and between strain TBN $37^{\mathrm{T}}$ and Haloplanus vescus $\mathrm{RO} 5-8^{\mathrm{T}}$ were $37.6 \%$ and $42.1 \%$, respectively, which indicated that strain $\mathrm{TBN} 37^{\mathrm{T}}$ represents a distinct genospecies of Haloplanus since the generally accepted threshold value to separate two species is less than $70 \%$ (Stackebrandt \& Goebel, 1994).

This polyphasic taxonomic study provides evidence that strain $\mathrm{TBN} 37^{\mathrm{T}}$ represents a novel species of the genus Haloplanus, for which the name Haloplanus aerogenes sp. nov. is proposed. Characteristics that distinguish strain $\mathrm{TBN} 37^{\mathrm{T}}$ from Haloplanus natans JCM $14081^{\mathrm{T}}$ and Haloplanus vescus $\mathrm{RO} 5-8^{\mathrm{T}}$ are shown in Table 1.

\section{Description of Haloplanus aerogenes sp. nov.}

Haloplanus aerogenes (ae.ro'ge.nes. Gr. n. aer aeros, air; N.L. suff. -genes (from Gr. v. gennaô to produce) producing; N.L. adj. aerogenes gas-producing).

Cells are pleomorphic and flat $(1.0-2.0 \mu \mathrm{m})$ under optimal growth conditions and stain Gram-negative. Cells contain gas vesicles. Colonies on agar plates containing $2.1 \mathrm{M} \mathrm{NaCl}$ are pink, elevated and round. Chemo-organotrophic and aerobic. Growth occurs at $25-50{ }^{\circ} \mathrm{C}$ (optimum, $37-40{ }^{\circ} \mathrm{C}$ ), with 1.4-5.1 M NaCl (optimum, 2.1 M NaCl), with 01.0 $\mathrm{M} \mathrm{MgCl}_{2}$ (optimum, $0.01 \mathrm{M} \mathrm{MgCl}_{2}$ ) and at $\mathrm{pH}$ 6.0-9.0 (optimum, pH 7.5). Cells lyse in distilled water and the minimal $\mathrm{NaCl}$ concentration to prevent cell lysis is $8 \%$ $(w / v)$. Catalase- and oxidase-positive. Grows anaerobically in the presence of nitrate and produces gas. Does not grow under anaerobic conditions with arginine or DMSO. Nitrate reduction to nitrite is observed. $\mathrm{H}_{2} \mathrm{~S}$ is not produced from sodium thiosulfate. Positive for indole formation. Tween 80, casein, starch and gelatin are not hydrolysed. The following substrates are utilized as single carbon and energy sources for growth: D-glucose, D-mannose, D-galactose, sucrose, acetate, pyruvate, DL-lactate, L-alanine, L-arginine and L-glutamate. No growth on D-fructose, L-sorbose, D-ribose, D-xylose, maltose, lactose, starch, glycerol, D-mannitol, D-sorbitol, succinate, L-malate, fumarate, citrate, glycine, L-aspartate, L-lysine or L-ornithine. No acid is produced from sugars. Sensitive to the following antibiotics ( $\mu \mathrm{g}$ per disc, unless otherwise indicated): novobiocin (30), bacitracin (0.04 IU per disc), anisomycin (20), aphidicolin (20) and rifampicin (5). Resistant to the following antibiotics: erythromycin (15), penicillin G (10 IU per disc), ampicillin

Table 1. Characteristics that distinguish strain $\mathrm{TBN}^{\mathrm{T}} 7^{\mathrm{T}}$ from Haloplanus natans JCM $14081^{\top}$ and Haloplanus vescus $\mathrm{RO} 5-8^{\mathrm{T}}$

Strains: 1, TBN37 ${ }^{\mathrm{T}} ; 2$, Haloplanus natans JCM $14081^{\mathrm{T}}$ (Bardavid et al., 2007); 3, Haloplanus vescus RO5-8 ${ }^{\mathrm{T}}$ (Cui et al., 2010). +, Positive; - , negative. All data from this study.

\begin{tabular}{|lccc|}
\hline Characteristic & $\mathbf{1}$ & $\mathbf{2}$ & $\mathbf{3}$ \\
\hline Optimum $\mathrm{NaCl}(\mathrm{M})$ & 2.1 & 3.0 & 3.1 \\
Optimum pH & 7.5 & 7.0 & $6.0-6.5$ \\
Anaerobic growth with nitrate & + & - & - \\
Gas formation from nitrate & + & - & - \\
Utilization of: & & & \\
$\quad$ D-Galactose & + & - & - \\
$\quad$ D-Ribose & - & + & - \\
$\quad$ Maltose & - & - & + \\
$\quad$ Sucrose & + & - & - \\
$\quad$ L-Glutamate & + & - & - \\
$\mathrm{H}_{2} \mathrm{~S}$ formation & - & + & - \\
$\mathrm{G}+\mathrm{C}$ content $(\mathrm{mol} \%)$ & 64.1 & 66.2 & 62.1 \\
\hline
\end{tabular}


(10), chloramphenicol (30), neomycin (30), norfloxacin (10), ciprofloxacin (5), streptomycin (10), kanamycin (30), tetracycline (30), vancomycin (30), gentamicin (10) and nalidixic acid (30). The major polar lipids are PG, PGP-Me, PGS and one major glycolipid chromatographically identical to S-DGD-1. The DNA G $+\mathrm{C}$ content of the type strain is $64.1 \mathrm{~mol} \%$ (as determined by HPLC).

The type strain is $\mathrm{TBN} 37^{\mathrm{T}}\left(=\mathrm{CGMCC} 1.10124^{\mathrm{T}}=\mathrm{JCM}\right.$ $16430^{\mathrm{T}}$ ), isolated from Taibei marine solar saltern in Jiangsu province, China.

\section{Acknowledgements}

This work was supported by the National Natural Science Foundation of China (no. 30970006).

\section{References}

Bardavid, R. E., Mana, L. \& Oren, A. (2007). Haloplanus natans gen. nov., sp. nov., an extremely halophilic, gas-vacuolate archaeon isolated from Dead Sea-Red Sea water mixtures in experimental outdoor ponds. Int J Syst Evol Microbiol 57, 780-783.

Chun, J., Lee, J.-H., Jung, Y., Kim, M., Kim, S., Kim, B. K. \& Lim, Y.-W. (2007). EzTaxon: a web-based tool for the identification of prokaryotes based on $16 \mathrm{~S}$ ribosomal RNA gene sequences. Int J Syst Evol Microbiol 57, 2259-2261.

Cui, H.-L., Lin, Z.-Y., Dong, Y., Zhou, P.-J. \& Liu, S.-J. (2007). Halorubrum litoreum sp. nov., an extremely halophilic archaeon from a solar saltern. Int J Syst Evol Microbiol 57, 2204-2206.

Cui, H.-L., Zhou, P.-J., Oren, A. \& Liu, S.-J. (2009). Intraspecific polymorphism of $16 \mathrm{~S}$ rRNA genes in two halophilic archaeal genera, Haloarcula and Halomicrobium. Extremophiles 13, 31-37.

Cui, H.-L., Gao, X., Li, X.-Y., Xu, X.-W., Zhou, Y.-G., Liu, H.-C. \& Zhou, P.-J. (2010). Haloplanus vescus sp. nov., an extremely halophilic archaeon from a marine solar saltern, and emended description of the genus Haloplanus. Int J Syst Evol Microbiol 60, 1824-1827.

De Ley, J., Cattoir, H. \& Reynaerts, A. (1970). The quantitative measurement of DNA hybridization from renaturation rates. Eur $J$ Biochem 12, 133-142.

Dussault, H. P. (1955). An improved technique for staining red halophilic bacteria. J Bacteriol 70, 484-485.
Fitch, W. M. (1971). Toward defining the course of evolution: minimum change for a specific tree topology. Syst Zool 20, 406-416.

Gonzalez, C., Gutierrez, C. \& Ramirez, C. (1978). Halobacterium vallismortis sp. nov. An amylolytic and carbohydrate-metabolizing, extremely halophilic bacterium. Can J Microbiol 24, 710-715.

Gutiérrez, C. \& González, C. (1972). Method for simultaneous detection of proteinase and esterase activities in extremely halophilic bacteria. Appl Microbiol 24, 516-517.

Gutiérrez, M. C., Castillo, A. M., Kamekura, M. \& Ventosa, A. (2008). Haloterrigena salina sp. nov., an extremely halophilic archaeon isolated from a salt lake. Int J Syst Evol Microbiol 58, 2880-2884.

Huß, V. A. R., Festl, H. \& Schleifer, K. H. (1983). Studies on the spectrophotometric determination of DNA hybridization from renaturation rates. Syst Appl Microbiol 4, 184-192.

Kates, M. (1986). Techniques of lipidology, 2nd rev. edn. Amsterdam: Elsevier.

McDade, J. J. \& Weaver, R. H. (1959). Rapid methods for the detection of gelatin hydrolysis. J Bacteriol 77, 60-64.

Mesbah, M., Premachandran, U. \& Whitman, W. B. (1989). Precise measurement of the $\mathrm{G}+\mathrm{C}$ content of deoxyribonucleic acid by highperformance liquid chromatography. Int J Syst Evol Bacteriol 39, 159167.

Ng, W.-L., Yang, C.-F., Halladay, J. T., Arora, A. \& DasSarma, S. (1995). Protocol 25. Isolation of genomic and plasmid DNAs from Halobacterium halobium. In Archaea: a laboratory manual: Halophiles, pp. 179-180. Edited by S. DasSarma \& E. M. Fleischmann. Cold Spring Harbor, NY: Cold Spring Harbor Laboratory Press.

Oren, A., Ventosa, A. \& Grant, W. D. (1997). Proposed minimal standards for description of new taxa in the order Halobacteriales. Int J Syst Bacteriol 47, 233-238.

Oren, A., Arahal, D. R. \& Ventosa, A. (2009). Emended descriptions of genera of the family Halobacteriaceae. Int J Syst Evol Microbiol 59, 637-642.

Saitou, N. \& Nei, M. (1987). The neighbor-joining method: a new method for reconstructing phylogenetic trees. Mol Biol Evol 4, 406425.

Stackebrandt, E. \& Goebel, B. M. (1994). Taxonomic note: a place for DNA-DNA reassociation and 16S rRNA sequence analysis in the present species definition in bacteriology. Int J Syst Bacteriol 44, 846849.

Tamura, K., Dudley, J., Nei, M. \& Kumar, S. (2007). MEGA4: molecular evolutionary genetics analysis (MEGA) software version 4.0. Mol Biol Evol 24, 1596-1599. 